\title{
Determinan produksi perkebunan karet di Desa Purwasari Kabupaten Bungo
}

\author{
Rosmeli*; Dwi Hastuti \\ Prodi Ekonomi Pembangunan Fakultas Ekonomi dan Bisnis Universitas Jambi \\ *E-mail korespondensi : rosmeli@unja.ac.id
}

\begin{abstract}
Rubber plantations that used to be the mainstay of the community in Jambi Province are now being replaced by oil palm plantations, the same thing also happened in Purwasari Village, Bungo Regency. This study uses primary with respondents as many as 40 rubber farmers, from the results of the study, obtained the results together - the area of land, number of plants, age of plants, labor and fertilization costs have a significant effect on rubber production, while partially planted area and number of plants has a significant effect on rubber production, while the age of the plant, the number of laborers and the cost of fertilization have no significant effect on rubber production. Seen from the scale of production of rubber farmers in Purwasari Village are on the scale of production decreasing returns to scale.
\end{abstract}

Keywords: Land area, Number of plants, Fertilization costs, Rubber production

\begin{abstract}
Abstrak
Perkebunan karet yang dulu menjadi andalan masyarakat di Provinsi Jambi sekarang mulai digantikan oleh perkebunan kelapa sawit, hal yang sama juga terjadi di Desa Purwasari Kabupaten Bungo, dilihat dari luas lahan, lahan perkebunan karet luasnya semakin sedikit dikarenakan alih fungsi perkebunan karet menjadi perkebunan kelapa sawit. Penelitian ini menggunakan primer dengan responden adalah petani karet sebanyak 40 orang, dari hasil penelitian diperolah hasil secara bersama - sama luas lahan, jumlah tanaman, umur tanaman, tenaga kerja dan biaya pemupukan berpengaruh signifikan terhadap produksi karet, sedangkan secara parsial luas tanamah dan jumlah tanaman mempunyai pengaruh signifikan terhadap produksi karet, sedangkan umur tanaman, jumlah tenaga kerja dan biaya pemupukan mempunyai pengaruh yang tidak signifikan terhadap produksi karet. Dilihat dari Skala produksi petani karet di Desa Purwasari berada pada skala produksi decreasing returns to scale.
\end{abstract}

Kata Kunci: Luas lahan, Jumlah tanaman, Biaya pemupukan, Produksi karet

\section{PENDAHULUAN}

Sektor pertanian merupakan sector yang masih menjadi andalan di Indonesia, ini tidaklah mengherankan karena sebagian besar penduduk Indonesia masih bekerja pada sector pertanian. Salah sector yang memberikan kontribusi terhadap sector pertanian adalah sector perkebunan. Sektor perkebunan telah terbukti memberikan peranan penting bagi pembangunan pertanian nasional, baik dalam aspek ekonomi, social maupun keseimbangan pertanian nasional. Hal ini dilakukan dengan peremajaan, rehabilitasi, perbaikan mutu tanaman, penganekaragraman jenis dan pemanfaatkan lahan transmigrasi perkebunan. 
Menurut Taufik dan Saleh (2002) dalam Yulianita (2009) menyatakan bahwa komoditas unggulan memberikan dua sumbangan berupa efek langsung yang kemudian dapat meningkatkan pendapatan faktor-faktor produksi daerah dan pendapatan daerah yang akan menghasilkan permintaan yang membantu industri lokal untuk terus meningkat. Selanjutnya, menurut Tohir (1991), tingkat kesejahteraan petani dicerminkan keadaan usahatani yang sejahtera yaitu pada tingkat pendapatan petani tinggi. Oleh karena itu, peran sektor pertanian yang diberikan untuk pembangunan ekonomi, membuat sektor pertanian harus terus dikembangkan oleh pemerintah, namun pada kenyataanya peran sektor pertanian mengalami penurunan.

Fenomena penyebab penurunan produksi diantaranya dikemukakan Arifin (2001) dimana penurunan peran sektor pertanian disebabkan masih terlalu mengandalkan ketersediaan lahan pertanian. Jika terlalu mengandalkan tanah selalu berfikir bahwa semakin banyak lahan maka produksi akan meningkat, kondisi ini menyebabkan sering terjadinya pembukaan lahan baru dengan cara membakar hutan dan hal ini sangat termasuk kegiatan merusak. Menurut Daniel (2002) dalam usahatani faktor produksi pertanian mencakup beberapa diantaranya yaitu tanah, modal dan tenaga kerja. Selanjutnya, ada beberapa cara untuk meningkatkan produksi lahan yaitu dengan cara pemupukan dan perawatan sehingga tanaman menghasilkan produksi yang lebih banyak. Kemudian pada proses pengeluaran total usahatani terkait dengan gabungan nilai input yang digunakan atau pengeluaran jumlah input yang habis terpakai, sedangkan selisih antara pendapatan kotor usahatani dan total pengeluaran input faktor produksi dinamakan pendapatan bersih usahatani(Soekartawi, 1986).

Di Provinsi Jambi tanaman kelapa sawit dan karet merupakan tanaman yang mendominasi sector perkebunan dan sangat potensial untuk dikembangkan. Luas lahan perkebunan kelapa sawit mencapai 400.168 ha produksi kelapa sawit sebesar 898,24 ribu ton pertahun serta karet mencapai 595.473 ha dengan hasil karet 312.925 ton. Sementara itu, jumlah petani kelapa sawit mencapai 177.802 kepala keluarga (KK). Luas perkebunan karet rakyat mencapai 646.878 ha dan jumlah petani karet sekitar 251.403 KK. Banyaknya petani yang menggeluti usaha perkebunan sawit dan karet di Jambi menjadi modal utama untuk terus meningkatkan peran kebun sawit dan karet dalam memajukan ekonomi rakyat dan daerah.

Perkebunan karet hampir berada disetiap Kabupaten dalam Provinsi Jambi, pada tahun 2016 luas perkebunan terbesar berada pada Kabupaten Merangin sebesar 61.758 Ha, disusul dengan Kabupaten Sarolangun sebesar 58.394 Ha, Kabupaten Tebo seluas $50.314 \mathrm{Ha}$ dan Kabupaten Bungo seluas 45.337 Ha. Kabupaten yang memiliki luas perkebunan Karet terkecil adalah Kabupaten Kerinci seluas $354 \mathrm{Ha}$.

Salah satu daerah yang masih mengandalkan perkebunan karet sebagai mata pencaharian utama mereka di Kabupaten Bungo adalah Desa Purwasari. Desa ini memiliki jumlah penduduk terbesar di Kecamatan Pelepat Ilir dengan jumlah penduduk sebanyak 6.165 orang dan luas perkebunana karet seluas 3.948 Ha yang merupakan luas perkebunan karet cukup besar di Kecamatan Pelepat Ilir Kabupaten Bungo.

Desa Purwasari merupakan Desa yang tergolong sudah maju, dengan banyaknya lembaga keuangan yang berada di Desa tersebut, adanya pasar dan banyaknya aktivitas perekonomian dilakukan di Desa ini. Meskipun sudah tergolong Desa yang maju, masyarakat Desa ini masih menggantungkan hidup mereka pada perkebunan karet yang telah mereka miliki sejak lama, produktifitas tanaman karet akan sangat menentukan tingkat perekonomian sebagian masyarakat yang berada di Desa ini.

\section{METODE}

\section{Jenis dan sumber data}

Data yang digunakan dalam penelitian ini adalah data sekunder dan data primer. Data sekunder berupa:Data luas lahan perkebunan karet di Desa Purwasari,Data jumlah 
petani karet di Desa Purwasari, Data Monografi Desa. Data sekunder bersumber dari kantor Kecamatan Pelepat Ilir dan kantor Desa Purwosari yang berhubungan dengan penelitian, sedangkan data primer di perolah dari survey lapangan. Sedangkan untuk data primer berupa meliputi: Data Luas Kebun Karet Responden, Data Jumlah tanaman karet , Data Umur Tanaman, Data tenga kerja, Data jumlah pupuk dan Data jumlah produksi karet

\section{Pengumpulan data dan penarikan sampel}

Untuk mengumpulkan data Primer maka digunakan beberapa metode seperti: metode observasi, metode wawancara, dan metode quisioner. Untuk mengambil sampel dalam penelitian ini digunakan metode sensus. Dengan metode sensus, maka semua petani karet yang ada di Desa Purwasari dijadikan sampel dalam penelitian ini. Jumlah Petani Karet di Desa Purwasari sebanyak 40 responden yang dijadikan sampel dalam penelitian ini.

\section{Metode analisis data}

Untuk menjawab tujuan pertama maka digunakan model regresi berganda cob douglass, dengan formulasi sebagai berikut: Dimana:

$$
\log Y=\beta_{0}+\beta_{1} \log x_{1}+\beta_{2} \log x_{2}+\beta_{3} \log x_{3}+\beta 4 \log x 4+\beta_{5} \log x_{5}+e i
$$

$\begin{array}{ll}\beta_{0} & : \text { Kostanta } \\ \beta_{1}, \beta_{2}, \beta_{3}, \beta_{4} & : \text { Koefisien Regresi } \\ \mathrm{Y} & : \text { Produksi Karet } \\ \mathrm{X}_{1} & : \text { Luas Lahan } \\ \mathrm{X}_{2} & : \text { Jumlah Tanaman } \\ \mathrm{X}_{3} & \text { : Umur Tanaman } \\ \mathrm{X}_{4} & \text { : Bumlah Tenaga Kerja } \\ \mathrm{X}_{5} & \text { Biaya Pemupukan }\end{array}$

Untuk menjawab tujuan kedua maka Raturn to Scale (RTS) yang merefleksikan peningkatan secara proporsional dalam input untuk meningkatkan output yaitu: 1).Constant Returns to Scale (CRS), bila $\beta_{1}, \beta_{2}, \beta_{3}, \beta_{4}, \beta_{5}=1$. Ini terjadi bila peningkatan proposional dalam semua input akan menghasilkan penggandaan output secara proporsional. 2).Increasing Returns to Scale (IRS), bila $\beta_{1}, \beta_{2}, \beta_{3}, \beta_{4}, \beta_{5}>1$. Ini terjadi bila peningkatan proporsional semua input akan menghasilkan output yang lebih besar. 3).Decreasing Returns to Scale (DRS), bila $\beta_{1}, \beta_{2}, \beta_{3}, \beta_{4}, \beta_{5}<1$. Ini terjadi bila peningkatan proporsional dari semua input akan menghasilkan peningkatan output secara lebih kecil

\section{Pengujian hipotesis}

\section{Uji-F}

Tujuan uji simultan untuk mengetahui pengaruh variabel variabel independen secara bersaman terhadap variablel dependen. Menurut Ghozali(2016, h.96) Uji F menguji hipotesa bahwa b1, b2, b3 secara simultan sama dengan nol. Uji ini pada dasarnya untuk menunjukkan apakah semua variable bebas yang dimasukkan dalam model mempunyai pengaruh secara bersama-sama terhadap variable terikat dengan cara: 1).Menentukanhipotesis yang akandiuji (Ho dan Ha), 2)Menentukan level of significance $(\alpha)$ tertentu, 3).Menentukan criteria pengujian dengan membandingkan nilai F-tabel dan F-hitung, 3).Menarik kesimpulan. Apabila F-hit lebih besar dari pada F-tabel maka Ho ditolak, artinya variable bebas secara bersama-sama mempengaruhi variable tidak bebas. Nilai F-hit dicari dengan cara sebagai berikut: 
Dimana:

$$
F-\text { hitung }=\frac{R^{2} /(k-1)}{\left(1-R^{2}\right) /(n-k)}
$$

$\mathrm{R}^{2}=$ koefisien determinasi

$\mathrm{k}=$ jumlah variable bebas

$\mathrm{n}=$ jumlah observasi

Maka dengan derajat tertentu, apabila F- hitung < F- table, Maka Ho yang diterima artinya secara bersama-sama variabel independen secara signifikan tidak di pengaruhi variabel dependen. Sedangkan jika F- hitung> F- table, Maka Ho yang diterima artinya secara bersama-sama variable independen secara signifikan di pengaruhi variable dependen

\section{Uji-t}

Menurut Ghozali (2016, h.97) Uji statistik t menggambarkan seberapa jauh pengaruh satu variabel independen secara individual terhadap variabel dependen. Dengan derajat keyakinan tertentu, maka jika t- hitung < t table, Maka Ho diterimadan Ha di tolak, artinya secara individu tidak ada pengaruh yang berarti antara variabel independent terhadap variabel dependen. Sedangkan jika t- hitung > t table, Maka Ho di tolak dan Ha di terima, artinya secara individu ada pengaruh yang berarti antara variabel independent terhadap variabel dependen. Nilai t-hit dicari dengan cara sebagai berikut:

Dimana:

$$
t-_{\text {hitung }}=\frac{\beta i}{S E(\beta i)}
$$

$\beta i=$ nilai koefisien regresi

$S E=$ nilai standar error dari $b i$

\section{Koefisien determinasi $\left(\mathbf{R}^{2}\right)$}

Koefisien determinasi ini mengukur seberapa jauh kemampuan model dalam menerangkan variasi variable terikat. Koefisien ini nilainya antara nol (0) sampai dengan satu (1). Semakin besar nilai koefisien tersebut makavariabel-variabel bebas lebih mampu menjelaskan variasi variable terikatnya. Untuk menghitung besarnya determinan $\left(\mathrm{R}^{2}\right)$ dapat digunakan rumus sebagai berikut (Gujarati, 2003):

Dimana:

$$
R^{2}=\frac{E S S}{T S S}=1-\frac{R^{2} /(k-1)}{\left(1-R^{2}\right) /(n-k)}
$$

$\mathrm{R}^{2} \quad=$ Koefisien determinasi

ESS =Jumlah kuadrat residual

TSS =Total jumlah kuadrat residual

$\mathrm{n} \quad=$ Jumlah observasi

$\mathrm{K}=$ Jumlah parameter (termasuk intersep)

\section{Uji asumsi klasik}

Untuk itu, perlu dilakukan pengujian terhadap model regresi yang telah dibuat, agar model yang dibuat dapat memenuhi sifat BLUE (best linier unbiased estimator). Ada 
beberapa jenis uji yang harus dilakukan sebelum hasil analisis diinterpretasikan, yaitu uji normalitas, uji multikolinieritas, uji heteroskedastisitas, dan uji autokorelasi.

\section{Uji normalitas}

Uji normalitas digunakan untuk menentukan apakah data yang telah dikumpulkan berdistribusi normal atau diambil dari populasi normal. Uji normalitas juga melihat apakah model regresi yang digunakan sudah baik. Model regresi yang baik adalah memiliki distribusi data normal atau mendekati normal (Ghozali, 2011). Dalam penelitian ini ujinormalitas menggunakan Kolmogorov-Smirnov. Dasar pengambilan keputusan adalah melihat angka probabilitas, dengan ketentuan: jika probabilitas $>0,05:$ hipotesis diterima karena data berdistribusi secara normal, dan probabilitas $<0,05:$ hipotesis ditolak karena data tidak berdistribusi normal.

\section{Uji multikolinieritas}

Adanya korelasi atau hubungan linier antara variable independen dalam regresi berganda disebut multikolinieritas (Ghozali,2016, h.103). Uji multikolinearitas bertujuan menguji apakah dalam regresi ditemukan adanya korelasi antar variable bebas (independen). Pendeteksian keberadaan multikolinearitas dapat dilihat dari nilai tolerance dan lawannya Variance Inflation Factor $(V I F)$. Kedua ukuran ini menunjukkan variable independen manakah yang dijelaskan oleh variable independen lainnya. Apabila nilai tolerance di atas 10 persen dan VIF di bawah 10, maka dapat disimpulkan bahwa model regresi bebas dari multikolinearitas (Ghozali, 2011).

\section{Uji autokorelasi}

Auto korelasi merupakan korelasi antar satu variabel gangguan dengan variabel gangguan yang lain. Adanya autokorelasi dalam model regresi akan mengakibatkan model regresi tersebut memiliki karakteristik sebagai berikut (Widarjono, 2009). Dengan adanya autokorelasi dalam model regresi, model yang dihasilkan tidak memiliki sifat BLUE, namun hanya LUE. Jika estimator atau model tidak mempunyai varian yang minimum maka memiliki konsekuensi sebagai berikut (Widarjono, 2009).

\section{Uji heteroskedastisitas}

Uji heteroskedastisitas bertujuan menguji apakah dalam regresi terjadi ketidaksamaan varians dari residual satu pengamatan kepengamatan yang lain. Kriteria multikolinearitas menurut Ghozali, (2011) terjadi: 1).Apabila ada pola tertentu, seperti titik-titik yang ada membentuk pola tertentu yang teratur (bergelombang, melebar kemudian menyempit), maka mengindikasikan telah terjadi heteroskedastisitas. 2).Apabila terdapat variabel bebas yang berpengaruh secara signifikan pada tingkat signifikansi 5\% terhadap residual kuardrat, maka terjadi heteroskedastisitas.

\section{HASIL DAN PEMBAHASAN}

\section{Faktor - faktor yang mempengaruhi produksi Karet di Desa Purwasari}

Produksi karet sangat dipengaruhi oleh beberapa hal diantaranya adalah luas lahan, jumlah tanaman, umur tanaman, jumlah tenaga kerja dan pemupukan yang dilakukan. Berdasarkan hasil olah data, maka dilakukan uji hipotesis untuk variable - variable yang ada dalam penelitian ini baik secara overall maupun secara parsial.

Berdasarkan hasil uji secara keseluruhan diperoleh nilah F hitung sebesar 14.920 dengan probabilita sebesar 0.00, ini berarti luas lahan, jumlah tanaman, umur tanaman, jumlah tenaga kerja dan biaya pemupukan secara bersama - sama berpengaruh signifikan terhadap produksi karet di Desa Purawasari. 
Berdasarkan nilai uji t sebesar 2.189 dengan probabilita sebesar 0.036, artinya luas lahan mempunyai pengaruh signifikan terhadap produksi karet di Desa Purwasari. Luas lahan memberikan pengaruh terhadap produksi karet, semakin luas lahan perkebunan karet, maka produksi karet yang dihasilkan juga semakin besar.

Jumlah tanaman mempunyai nilai uji t sebesar 7.209 dengan probabilita sebesar 0.000 , ini berarti jumlah tanaman karet mempunyai pengaruh yang signifikan terhadap produksi karet. Ini tidaklah mengherankan karena produksi karet sangat tergantung pada jumlah tanaman yang menghasilkan getah karet, semakin banyak jumlah tanaman maka produksi karet juga akan meningkat.

Umur Tanaman karet mempunyai pengaruh yang tidak signifikan terhadap produksi karet, ini dapat dilihat dari nilai nilai uji t sebesar - 1.219 dengan probabilita sebesar 0.232. Umur tanaman akan mempengaruhi jumlah getah yang dihasilkan oleh tanaman karet, semakin tua umur tanaman maka semakin sedikit getah yang dihasilkan.

Nilai nilai uji t untuk jumlah tenaga kerja diperoleh sebesar -0.404 dengan probabilita sebesar 0.689 , ini berarti jumlah tenga kerja tidak berpengaruh signifikan terhadap produksi karet, hal ini dikarenakan jumlah tenaga kerja tidak memberikan kontribusi untuk peningkatan produksi karet, karena tenaga kerja hanya bertugas untuk mengumpulkan getah yang ada di perkebunan karet.

Biaya pemupukan tidak berpengaruh signifikan terhadap produksi karet, dengan nilai th sebesar -0.862 dengan probabilita 0.395 , ini berarti biaya pemupukan tidak memberikan terhadap peningkatan produksi keret karena karet yang ditanam oleh warga telah memiliki umur yang sudah tua.

Dari 5 variabel yang mempengaruhi produksi karet, 2 variabel yaitu luas tanah dan jumlah tanaman mempunyai pengaruh signifikan terhadap produksi karet, Hal ini sejalan dengan penelitian Hastuti.,dkk (2018) yang melakukan penelitannya pada tahun 2013 dimana faktor-faktor yang signifikan terhadap produksi karet dipengaruhi oleh luas lahan, dan jumlah tanaman. Akan tetapi setelah dilakukan memperluas variable penelitian pada tahun 2018 diperoleh bahwa variable umur tanaman, jumlah tenaga kerja dan biaya pemupukan mempunyai pengaruh yang tidak signifikan terhadap produksi karet. Perbedaan hasil penelitan pada variable tenaga kerja penelitian Hastuti, dkk(2018) dimana penelitian ini dipengaruhi oleh perubahan pola manajemen dan kondisi dari tanaman karet yang semakin tua sehingga variable jumlah tenaga kerja menjadi tidak signifikan terhadap produksi karet. Faktor lain juga seperti peralihan tanaman karet menjadi kelapa sawit membuat tanaman karet tidak produktif. Masa peralihan tanaman karet menjadi kelapa sawit dimana petani akan membiarkan tanaman karet tetap tumbuh dan menambah tanaman baru yaitu kelapa sawit. Hal ini menyebabkan nutrisi seperti pupuk, dan air yang diserap tanaman karet akan berkurang sehingga menyebabkan produksi karet menurun. Berdasarkan hasil olah data dapat diketahui persamaan sebagai berikut:

\section{$\log Y=\beta_{0}+\beta_{1} \log X_{1}+\beta_{2} \log X_{2}+\beta_{3} \log X_{3}+\beta_{4} \log X_{4}+\beta_{5} \log X_{5}+$ ei $=2.242+0.834 \log X_{1}+0.774 \log X_{2}-0.474 \log X_{3}-0.144 \log X_{4}-0.026 \log X_{5}+$ ei}

Dari hasil olah data diperoleh nilai konstanta sebesar 2.242, ini berarti jika luas lahan, jumlah tanaman, umur tanaman, jumlah tenaga kerja dan biaya pemupukan tetap maka produksi karet di Desa Purwasari akan meningkatan sebesar 2.242 persen.

Nilai koefieisen regresi $\beta_{1}$ sebesar 0.834 ini berarti jika pertambahan 1 persen luas lahan akan meningkatkan produksi karet sebesar 0.834 persen dengan asumsi factor lain dianggap tetap.

Nilai koefieisen regresi $\beta_{2}$ sebesar 0.774 , ini berarti jika penambahan 1 persen jumlah tanaman karet akan meningkatkan produksi karet sebesar 0.774 persen dengan asumsi factor lain dianggap tetap. Koefieisen regresi $\beta_{3}$ sebesar - 0.474 ini berarti jika 
penambahan umur tanaman meningkat tenaga kerja sebesar 1 persen, maka produksi karet akan menurun sebesar 0.474 persen.

Koefieisen regresi $\beta_{4}$ sebesar - 0.144, ini berarti jika jumlah tenaga kerja bertambah sebesar 1 persen, maka produksi karet akan mengalami penurunan sebesar 0.144 persen

Koefieisen regresi 5 sebesar -0.026 ini berarti, jika penambahan pupuk sebesar 1 persen maka produksi karet di Desa Purwasaria akan mengalami penurunan sebesar 0.026 dengan asumsi factor lain dianggap tetap.

Untuk nilai koefiesien determinasi diperoleh sebesar 0,693 ini berarti 69.3 persen produksi karet di Desa Purwasari dipengaruhi oleh factor - factor yang ada didalam penelitian ini sedangkan sisanya 30.7 persen produksi karet dipengaruhi oleh factor factor lain diluar penelitian ini.

\section{Uji asumsi klasik}

Untuk melihat apakah ada keterkaitan antara satu variable penelitan dengan variable yang lain dalam penelitian ini, maka dilakukan beberapa uji asumsi klasik seperti uji normalitas, uji autokorelasi, uji heterokedastisitas, dan uji multikolinearitas.

\section{Uji normalitas data}

Dari hasil uji kolmogorov-smirnovn pada Tabel 1 diperoleh nilai asymp sig pada output kologrov sebesar $0.062>0.05$, ini berarti data yang digunakan dalam penelitian ini berdistribusi secara normal.

Tabel 1. Hasil uji Kolmogorov-Smirnov Test

\begin{tabular}{llr}
\hline \multicolumn{2}{c}{ One-Sample Kolmogorov-Smirnov Test } \\
\hline & \multicolumn{2}{c}{$\begin{array}{c}\text { Unstandardized } \\
\text { Residual }\end{array}$} \\
\hline $\mathrm{N}$ & \multicolumn{1}{c}{39} \\
\hline Normal Parameters ${ }^{\mathrm{a}}$ & Mean & .0000000 \\
& Std. Deviation & .29472629 \\
Most Extreme & Absolute & .230 \\
Differences & Positive & .103 \\
& Negative & -.230 \\
Kolmogorov-Smirnov Z & 1.437 \\
Asymp. Sig. (2-tailed) & .062 \\
\hline a. Test distribution is Normal. \\
Sumber: Data diolah,2018
\end{tabular}

\section{Uji autokorelasi}

Berdasarkan hasil uji autokorelasi diperoleh hasil run test diperoleh nilai asymp sig sebesar 0.052 , ini berarti tidak terdapat autokorelasi antara satu variable dengan variable lain karena nilai $0.052>0.005$.

Tabel 2. Hasil uji autokorelasi

\begin{tabular}{lc}
\hline & Unstandardized Residual \\
\hline Test Value & .06666 \\
Cases $<$ Test Value & 19 \\
Cases >= Test Value & 20 \\
Total Cases & 39 \\
Number of Runs & 14 \\
Z & -1.944 \\
Asymp. Sig. (2-tailed) & .052 \\
\hline
\end{tabular}

\section{a. Median}

Sumber: Data diolah, 2018 


\section{Uji heterokedastisitas}

Menurut Ghozali (2016, h.137) menyatakan bahwa apabila nilai signifikansi $>0.05$ maka tidak terdapat gejala heterokedastisitas. Dari hasil uji herekedastisitas diketahui bahwa nilai asymp sig masing masing variable menunjukkan angka $>0.05$, ini berarti tidak terdapat heterokedastisitas.

Tabel 3. Hasil uji heterokedastisitas

\begin{tabular}{|c|c|c|c|c|c|}
\hline \multirow[t]{2}{*}{ Model } & \multicolumn{2}{|c|}{$\begin{array}{c}\text { Unstandardized } \\
\text { Coefficients }\end{array}$} & \multirow{2}{*}{$\begin{array}{c}\begin{array}{c}\text { Standardized } \\
\text { Coefficients }\end{array} \\
\text { Beta } \\
\end{array}$} & \multirow[t]{2}{*}{$\mathbf{t}$} & \multirow[t]{2}{*}{ Sig. } \\
\hline & B & Std. Error & & & \\
\hline 1 (Constant) & $-8.803 \mathrm{E}-16$ & .610 & & .000 & 1.000 \\
\hline x1 & .000 & .381 & .000 & .000 & 1.000 \\
\hline $\mathrm{x} 2$ & .000 & .107 & .000 & .000 & 1.000 \\
\hline $\mathrm{x} 3$ & .000 & .389 & .000 & .000 & 1.000 \\
\hline $\mathrm{x} 4$ & .000 & .356 & .000 & .000 & 1.000 \\
\hline $\mathrm{x} 5$ & .000 & .030 & .000 & .000 & 1.000 \\
\hline
\end{tabular}

a. Dependent Variable: Unstandardized Residual

Sumber: Data diolah, 2018

\section{Uji multikolineritas}

Menurut Ghozali (2016: 103) Jika nilai VIF lebih besar dari 10 dan nilai tolerance value kurang dari 0,1 maka terjadi multikolinieritas. Untuk uji multiko diperoleh nilai VIF kecil dari 10 dan nilai tetolorence yang lebih besar dari 0.1 maka data dalam penelitian bebas dari masalah multikolinieritas.

Tabel 4. Hasil uji multikolinearitas

\begin{tabular}{llrcc}
\hline \multirow{2}{*}{ Model } & \multicolumn{3}{c}{ Collinearity Statistics } \\
\cline { 2 - 5 } & B & Tolerance & VIF \\
\hline 1 & Constant) & 2.242 & & \\
x1 & .834 & .535 & 1.869 \\
x2 & .774 & .831 & 1.203 \\
x3 & -.474 & .923 & 1.084 \\
& x4 & -.144 & .766 & 1.306 \\
x5 & -.026 & .538 & 1.858 \\
\hline
\end{tabular}

Sumber: Data diolah, 2018

\section{Skala produksi petani karet di Desa Purwasari}

Menurut Koutsoyiannis (1975) menyatakan unsur skala ekonomis dan efisiensi di dalam usahatani menggambarkan unsur-unsur yang perlu di masukkan kedalam model fungsi produksi usahatani. Kemudian dalam perubahan output produksi tergambar pada skala pengembalian produksi atau yang lebih dikenal dengan skala pengembalian (Return to scale). Untuk melihat apakah produksi karet yang dilakukan oleh para petani Karet di Desa Purwasari dalam kondisi contant, increasing ataupun decreasing maka dihitung nilai return to scale sebagai berikut:

$$
\begin{aligned}
\beta & =2.242+0.834 \log \mathrm{X}_{1}+0.774 \log \mathrm{X}_{2}-0.474 \log \mathrm{X}_{3}-0.144 \log \mathrm{X}_{4}-0.026 \log \mathrm{X}_{5}+\text { ei } \\
\beta & =0.834+0.774-0.474-0.144-0.026 \\
& =0.964
\end{aligned}
$$

Dari hasil perhitungan diatas diketahui bahwa Perkebunan Karet Masyarakat di Desa Purwasari dalam kondisi (decreasing returns to scale), ini terjadi bila peningkatan 
proporsional dari semua input akan menghasilkan peningkatan output secara lebih kecil. Jika output bertambah secara proporsi yang lebih kecil dari pada kenaikan seluruh inputnya, terdapat hasil produksi yang turun atas skala produksinya $(\varepsilon p<1)$.

The law of dimishing return menyatakan jika input ini dianggap konstan atau tidak berubah, maka ketika satu input tertentu ditambahkan dalam proses produksi, mula-mula tambahan outputnya akan mengalami peningkatan, akan tetapi pada saat input tersebut ditambahkan hingga titik tertentu, maka tambahan output yang dihasilkan akan mengalami penurunan.misalnya dengan peningkatan skala input sebesar $100 \%$ ternyata hanya mampu menghasilkan peningkatan output sebesar $75 \%$.

Kondisi decreasing return to scale ini terjadi dikarenakan perkebunan karet bukan merupakan mata pencaharian pokok masyarakat di Desa Purwasari, perkebunan karet yang luas lahan terus menurun yang juga berdampak pada penurunan jumlah produksi mengakibatkan sector ini menjadi sector pendamping bagi penghasilan warga masyarakat. Masyarakat di Desa Purwasari telah menggantikan posisi perkebunan karet dengan perkebunan sawit, sehingga usaha masyarakat untuk meningkatkan hasil produksi perkebunan karet menjadi tidaklah maksimal, seringkali mereka menebang pohon karet mereka ketika ada warga yang membutuhkan untuk kayu bakar yang kemudian karet yagn sudah ditebang akan diganti dengan tanaman sawit, hingga menjadi suatu ke khawatiran tersendiri bila suatu saat nanti perkebunan karet ini telah hilang dari Desa Purwasari.

Karet merupakan komoditas unggulan Provinsi Jambi pada waktu dulu, seiring dengan waktu perkebunan karet mulai digantikan dengan perkebunan kelapa sawit. Pemerintah telah melakukan berbagai usaha untuk tetap mempertahankan perkebunan karet menjadi perkebunan masyarakat yang diminati oleh masyarakat, salah satunya dengan replanting karet tetapi program ini belum berhasil secara baik, hal ini tidaklah mengerankan karena keinginan masyarakat untuk menanam dan membudidayaka karet semakin jauh menurun. Faktor utama adalah harga karet yang selalu berada jauh dari harapan para petani ditambah lagi dengan produksi karet yang jauh lebih sedikit dibandingkan dengan produksi karet. Jika para petani tidak lagi membudidayakan karet maka pada suatu saat harga karet akan melonjak sangat tinggi dikarenakan supply yang sedikit dengan permintaan akan karet yang begitu besar, pada saat tersebut yang menikmati bukanlah para petani kita tetapi para petani luar Provinsi atau bahkan orang luar negeri seperti Malaysia yang masih terus membudidayakan tanaman karet.

Kebijakan pemerintah dengan memberikan bantuan kepada para petani karet berupa pemberian bantuan bibit, pupuk dan bantuan modal untuk menambah lahan perkebunan merupakan salah satu cara untuk meningkatkan keinginan masyarakat dalam membudidayakan perkebunan karet disertai dengan perbaikan harga dari getah karet itu sendiri.

\section{KESIMPULAN DAN SARAN}

\section{Kesimpulan}

Secara bersama - sama luas lahan, jumlah tanaman, umur tanaman, tenaga kerja dan biaya pemupukan berpengaruh signifikan terhadap produksi karet, sedangkan secara parsial luas tanamah dan jumlah tanaman mempunyai pengaruh signifikan terhadap produksi karet, sedangkan umur tanaman, jumlah tenaga kerja dan biaya pemupukan mempunyai pengaruh yang tidak signifikan terhadap produksi karet.Skala produksi petani karet di Desa Purwasari berada pada skala produksi Decreasing returns to scale.

\section{Saran}

Meningkatkan produksi karet harus dimulai dari penambahan luas perkebunan karet sendiri, pemilihan bibit yang baik. Oleh karena itu ketertarikan para petani untuk kembali mengoptimalkan perkebunan karet harus kembali di upayakan dengan cara memperbaiki 
harga jual getah karet, dan tetap mempertahankan pada harga yang menguntungkan para petani, pemberian bibit tanaman karet yang baik dari pemerintah merupakan salah satu upaya untuk tetap mempertahankan keberadaan perkebunan karet. Kondisi decreasing return to scale juga diakibatkan oleh ketidak tertarikan warga untuk mengupayakan perkebunan karet mereka sampai dalam kondisi yang optimal. Peningkatan harga karet serta perbaikan input akan meningkatkan produksi perkebunan karet yang akan berdampak pada kondisi increasing return to scale.

\section{DAFTAR PUSTAKA}

Arifin, B. (2001). Spektrum Kebijakan Pertanian Indonesia. Telaah Struktur, Kasus, dan Alternatif Strategi. Erlangga: Jakarta.

Daniel M. (2002). Pengantar Ekonomi Pertanian,PT. Bumi Aksar: Jakarta.

Ghozali, I. (2011). Aplikasi Analisis Multivariate dengan Program SPSS. Universitas Diponegoro: Semarang

Ghozali, I.(2016).Aplikasi Analisis Multivariete IBM SPSS 23,Universitas Diponegoro: Semarang.

Hastuti,D., Arman,D., \& Rosmeli. (2018). Pengembangan Komoditas Kelapa Sawit dan Karet Serta Dampaknya Terhadap Pendapatan Petani di Kecamatan Pelepat Ilir. Jurnal Sains Sosio Humaniora.2(2), 92-104

Jonni, A., Arman, D.; \& Siti, H. (2015). Analisis Produksi dan Pendapatan Petani Karet di Kabupaten Bungo. Jurnal Perspektif Pembiayaan dan Pembangunan Daerah, 2(4), 201-208.

Junaidi, J. (2014). Statistik Deskriptif dengan Microsoft Office Excel. FEB UNJA: Jambi Koutsoyiannis, A. (1975). Modern Microeconomic. The Macmillan Press. Ltd: London

Martin.S., Yulmardi.Y., \& Adi Bhakti. (2018). Pengaruh PDRB Sektor Pertanian, Nilai Tukar Petani dan Investasi Sektor Pertanian Terhadap Penyerapan Tenaga Kerja Sektor Pertanian Provinsi Jambi. e-Jurnal Ekonomi Sumberdaya dan Lingkungan, 7 (1), 1-12

Rezky, F.D., Hari Prihanto,P., \& Kusuma Edy. J. (2016). Analisis Penyerapan Tenaga Kerja Pada Sektor Pertanian di Kabupaten Tanjung Jabung Barat. E-Jurnal Ekonomi Sumberdaya dan Lingkungan, 5(1), 19-25

Soekartawi, (1989) Analisis Usaha Tani, UI Press:Jakarta

Soekartawi. (2005). Analisis Usahatani. UI Press: Jakarta

Tambunan,M. (2010). Menggagas Perubahan Pendekatan Pembangunan Menggerakkan Kekuatan Lokal Dalam Globalisasi Ekonomi.Graha Ilmu: Yogyakarta

Tohir, K. (1991). Seuntai pengetahuan usaha tani Indonesia. Rineka Cipta: Jakarta

Yulianita, A. (2009). Analisis Sektor Unggulan dan Pengeluaran Pemerintah di Kabupaten Ogan Komering Ilir. Jurnal Ekonomi Pembangunan: 7(2),70-85. 